NASZA DERMATOLOGIA Onlin OUR DERMATOLOGY Online

Source of Support: Nil

Competing Interests: None

\section{SPLINTER HEMORRHAGE AS A SIDE EFFECT OF CIPROFLOXACIN}

\author{
Ilkay Bozkurt \\ Department of Infectious Diseases, Afsin Government Hospital, Kahramanmaras, \\ Turkey
}

Corresponding author: Dr. Ilkay Bozkurt

drilkaybozkurt@gmail.com
Sir

A 40-year-old man presented painless red lesions under his fingernails that appeared after ciprofloxacin treatment. He was complaining about fever, abdominal pain and urgency with urination. Urine sample obtained and bacteriologic examination performed. According to urinalysis and culture results, patient evaluated as urinary tract infection and oral ciprofloxacin was initiated. He had a history of kidney stone. One week later on physical examination, at an outpatient clinic control linear reddish-brown streaks were noted on both fingernails (Fig.1). The patient had no history of trauma to his nails and had no underlying systemic disease in his past medical history. He was not taking any medication except ciprofloxacin. His personal and family histories were unremarkable. Two weeks after the initial presentation, both fingernails showed signs of resolution without treatment.

Splinter hemorrhages are nonblanchable, $1-$ to $3 \mathrm{~mm}$, red to reddish-brown, longitudinal hemorrhages appearing under the nail plate [1]. They occur in the dermis after rupture of the capillaries that follow the linear configuration of the epidermaldermal ridges [2]. The blood attaches to the nail plate and moves distally as the nail grows. Splinter hemorrhages can be caused by environmental factors, skin disorders, systemic diseases, and medication use. However, nail trauma (e.g., from sports, housework,) is the most common cause, accounting for 20 percent of cases [1-4]. Splinter hemorrhages could be associated with nail psoriasis, but can also occur with eczema, vasculitis, or onychomycosis [1]. Systemic disease may be the cause if the splinter hemorrhages appear in several nails, are located in the proximal portion of the nail plate, or are painful $[1,6]$. Petechiae and splinter hemorrhages are classic lesions of subacute endocarditis, especially when accompanied by fever, Roth spots, Osler nodes, Janeway lesions, or a murmur. Splinter hemorrhages can occur with systemic lupus erythematosus, along with other nail changes such as periungual telangiectasias, hyperkeratotic ragged cuticles, onycholysis, and red lunula [8].
Splinter hemorrhages can be an adverse effect of medications that impair blood vessels in the nail bed, although this is uncommon. These lesions are usually dose-related, involve several or all nails, and resolve after the medication is discontinued [8]. In the present case all lesions resolved day by day after the cession of ciprofloxacin treatment. Medications that may lead to splinter hemorrhages include antithrombotics and anticoagulants, such as aspirin and warfarin; cancer chemotherapeutic agents, such as taxanes; tetracycline; and ganciclovir [9-11]. idiopathic atraumatic splinter hemorrhages can occur in healthy individuals [1].

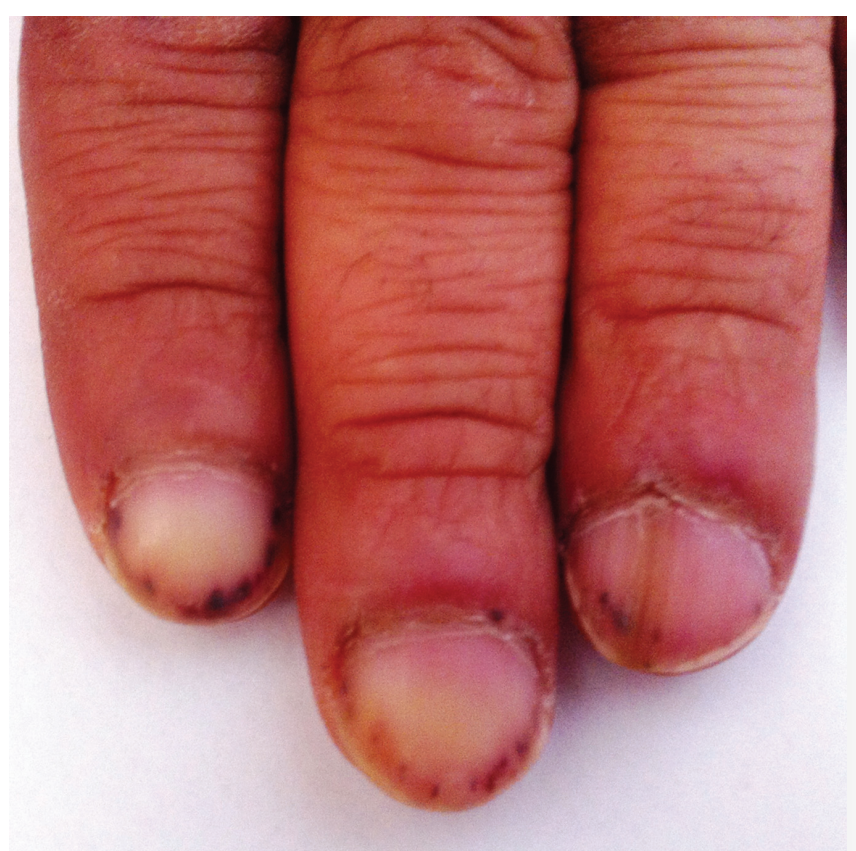

Figure 1. Splinter hemorrhages can be seen under each three fingernails. 


\section{REFERENCES}

1. Saladi RN, Persaud AN, Rudikoff D, Cohen SR: Idiopathic splinter hemorrhages. J Am Acad Dermatol. 2004;50:289-92.

2. Zaias N: The Nail in Health and Disease. 2nd ed. Stamford, Conn.: Appleton \& Lange; 1992.

3. Fitzpatrick TB, et al. Color Atlas and Synopsis of Clinical Dermatology. 4th ed. New York, NY: McGraw-Hill; 1990.

4. Miller A, Vaziri ND: Recurrent atraumatic subungual splinter hemorrhages in healthy individuals. South Med J. 1979;72:1418-20.

5. Mayeaux EJ Jr: Nail disorders. Prim Care. 2000;27:333-51.

6. Tosti A, Iorizzo M, Piraccini BM, Starace M: The nail in systemic diseases. Dermatol Clin. 2006;24:341-7.
7. McDonnell JK: Cardiac disease and the skin. Dermatol Clin. 2002;20:503-11.

8. Piraccini BM, Iorizzo M: Drug reactions affecting the nail unit. Dermatol Clin. 2007;25:215-21.

9. Varotti C, Ghetti E, Piraccini BM, Tosti A: Subungual haematomas in a patient treated with an oral anticoagulant (warfarin sodium). Eur J Dermatol. 1997;7:395-6.

10. Ghetti E, Piraccini BM, Tosti A: Onycholysis and subungual hemorrhages secondary to systemic chemotherapy (paclitaxel). J Eur Acad Dermatol Venereol. 2003;17:459-60.

11. Lorenzi S, D’Antuono A, Iorizzo M, Tosti A: Skin rash and splinter hemorrhages from ganciclovir. J Dermatolog Treat. 2003;14:177-8.

Copyright by Ilkay Bozkurt. This is an open access article distributed under the terms of the Creative Commons Attribution License, which permits unrestricted use, distribution, and reproduction in any medium, provided the original author and source are credited. 